John Carroll University

Carroll Collected

2018 Faculty Bibliography

Faculty Bibliographies Community Homepage

Fall 2018

\title{
Bibles, Ballots, and Bills: Political Resistance to Parochial Education in 1870s Ohio
}

James Gutowski

John Carroll University, jgutowski@jcu.edu

Follow this and additional works at: https://collected.jcu.edu/fac_bib_2018

Part of the Education Commons, and the Religion Commons

\section{Recommended Citation}

Gutowski, James, "Bibles, Ballots, and Bills: Political Resistance to Parochial Education in 1870s Ohio" (2018). 2018 Faculty Bibliography. 79.

https://collected.jcu.edu/fac_bib_2018/79

This Article is brought to you for free and open access by the Faculty Bibliographies Community Homepage at Carroll Collected. It has been accepted for inclusion in 2018 Faculty Bibliography by an authorized administrator of Carroll Collected. For more information, please contact connell@jcu.edu. 


\title{
Bibles, Ballots, and Bills: Political Resistance to Parochial Education in 1870s Ohio
}

\begin{abstract}
James A. Gutowski
The post-Civil War era opened a new chapter in the development of Catholic education in the United States. Seeking ways to forge stronger bonds of national unity, the Republican Party placed a high priority on public education as a means of forging a common American culture. Subsequently, members of the party viewed the growing number of Catholic schools, which offered an alternative to the public system, as a threat. The disproportionate growth of the Catholic population in Ohio alarmed the Republican Party, then holding many local and statewide offices. These officials sought to create legal and legislative barriers to hinder the influence of the Catholic Church, resulting in a defined wall of separation between public and parochial education in the state which would last for more than a hundred years.
\end{abstract}

Keywords: Ohio politics; parochial education; Republican Party; Hayes, Rutherford; Geghan, John J.; Cincinnati Bible War

The unrest that accompanied the development of parochial schools in the nineteenth century United States can be described as a struggle of shared values with conflicting ends. Both public and religious authorities recognized the importance of education for perpetuating their culture, but each side saw the other's goals as antithetical to their own. Similarly, both sides placed a high value on religious freedom but disagreed strongly about such freedom's meaning and application. For this reason, the propagation of Catholic schools across the nation was a source of conflict for most of the century.

The post-Civil War era brought a shift in this history of unrest. Before the war, much of the disruption was generated by Catholic leaders seeking fair treatment in the common schools. Failing this, Catholics sought financial support from tax dollars supporting education. After the Civil War, however, 
the initiatives causing unrest originated from public authorities seeking to arrest further development of the growing Catholic school system. Through a unique set of circumstances, Ohio became the epicenter for a post-war Catholic education controversy that would have nation-wide consequences in the presidential election of 1876. The enduring presence of Cincinnati's Archbishop John B. Purcell, who had been an outspoken advocate of state funding for parochial schools, provided a suitable target for anti-Catholic invective even after he had resigned himself to developing a school system independent of tax-funded support. The explosive growth of the Catholic population in Ohio alarmed Republican officials who sought ways to curb the expansion of the Church's presence in the state. Finally, an impolitic statement by a legislator-who was both a Catholic and a Democrat-provided the spark necessary to inflame Republican voters against the perceived dangers of Democratic collusion with the Catholic Church.

\section{Archbishop Purcell and the Antebellum Fight for Catholic Education}

By 1870, Catholics in Ohio had been under the leadership of Cincinnati Archbishop John Baptist Purcell for almost forty years. A former teacher, Purcell considered the cause of education a very important part of his episcopal ministry. ${ }^{1}$ When he arrived as bishop of Cincinnati in 1833, he found a rapidly growing city and the beginnings of a diocesan system boasting four schools and a seminary. ${ }^{2}$ Cincinnati's population grew from 25,000 in 1830 to 46,000 a decade later, and, by 1850 , it had exploded to $115,000 .^{3}$ In addition, many new arrivals, like Purcell himself, were Catholic immigrants who would provide fertile ground for the expansion of Catholic education in the diocese. Early in his administration, the new bishop sought a working relationship with public school authorities.

Cincinnati's Western Literary Institute and College of Professional Teachers had been established in 1831 with the mission: "to promote, by every laudable means, the diffusion of knowledge in regard to Education. . . ."4 Its members included William McGuffey, author of the Eclectic Reader series, Samuel Lewis, who would become Ohio's first Superintendent of Schools, and the

1. Transactions of the Sixth Annual Meeting of the Western Literary Institute and College of Professional Teachers Held in Cincinnati, October 1836 (Cincinnati: Executive Committee, 1837), 67.

2. Roger Fortin, Faith and Action: A History of the Archdiocese of Cincinnati 1821-1996 (Columbus: The Ohio State University Press, 2002), 39-44.

3. Steven J. Ross, Workers on the Edge: Work, Leisure, and Politics in Industrializing Cincinnati, 1788-1890 (New York: Columbia University Press, 1985), 72.

4. Transactions of the Sixth Annual Meeting, 33. 
Reverend Lyman Beecher, president of Lane Theological Seminary and scion of the Beecher family who would dominate much of American public life during the nineteenth century. ${ }^{5}$ Bishop Purcell joined this illustrious body and attended his first meeting in 1836 where he was invited to give an address on the philosophy of the human mind.

During the course of that meeting, Purcell was appointed to serve on a committee with Benjamin P. Aydelott, an Episcopalian minister and president of Woodward College in the city. They were assigned to explore the feasibility of developing a collection of Bible excerpts to be used as a textbook in the city's classrooms, however, they were not successful in cooperating. ${ }^{6}$ When the institute reconvened the next year, each man presented his own report. While they were in agreement that excerpting the Bible was not feasible and recommended using the Bible in its entirety, they differed on how the Good Book should be used. Purcell recommended part of each school day be set aside so that students could gather and study the Bible under the guidance of a minister from their own religious denomination. Aydelott, on the other hand, suggested all students study the King James Version, a Protestant version not approved by the Church for Catholic use. 7 The members of the institute voted to accept both reports and unanimously accepted the following resolution:

That this Convention earnestly recommend the use of the Bible in all our schools, to be read as a religious exercise, without denominational or sectarian comment, and that it is the deliberate conviction of this College, that the Bible may be so introduced in perfect consistency with religious freedom, and without offence to the peculiar tenets of any Christian sect. $^{8}$

This would unknowingly prove to be the high-water mark of public-Catholic cooperation in matters of education in Cincinnati.

By the 1850s additional boundaries between public and parochial school systems had evolved in Ohio, which caused Purcell, now an archbishop, to demand what he considered to be equitable treatment of Catholic schools by the state. His efforts elicited a harsh reaction from those who believed parochial schools undermined the mission of the common schools to create a more homogeneous American society. In 1851, the state legislature devel-

5. Ibid., 35 .

6. Ibid., 29.

7. Ibid., 41 .

8. Transactions of the Seventh Annual Meeting of the Western Literary Institute and College of Professional Teachers Held in Cincinnati, October, 1837 (Cincinnati: James R. Allbach, $1838), 13$. 
oped a new constitution which spelled out specific guidelines for education. It obligated the state government to fund a "thorough and efficient system of common schools throughout the state." At the same time, the document specifically forbade the allotment of such funding to any religious or sectarian organization. ${ }^{10}$

Implementing the directives laid out in the constitution, the legislature hammered out a systematic and thorough blueprint for public education in Ohio which became known as the Law of 1853. This legislation provided for greater centralization of administration and funding and created a Commissioner of Common Schools to oversee education across the state. Authority for school taxation was removed from local jurisdictions and assigned to county government. Direct supervision of the schools was assigned to school boards elected by all qualified voters, not just local taxpayers. ${ }^{11}$

As this law was being hammered out, a legislator proposed a clause that would require all parents of school-age children to send them to a common school for three months per year. Such a measure would have effectively prevented any other type of school, parochial included, from instructing children. Although the clause never became part of the law, it did prompt Archbishop Purcell to send a petition of protest. The archbishop then raised the stakes by sending a second petition requesting a portion of the tax dollars being collected for education be allocated for the parochial schools. His rationale was repeated by bishops in similar conflicts across the nation: parochial schools were doing the work of the state by providing the proper education that Catholic students could not receive in the inhospitable common schools and therefore deserved public money. ${ }^{12}$

During Holy Week of 1853, Archbishop Purcell issued a pastoral letter focusing largely on the school funding situation. ${ }^{13} \mathrm{He}$ used the timing of the letter to link his message to the theme of Jesus being unjustly condemned by an ignorant and docile majority "perverted by false teachers." 14 In the modern day, however, the majority was comprised largely of increasingly enlightened Catholics who could use their constitutional right to vote to cast out those modern-day false teachers from "the halls of legislation, the [city]

9. Ohio Constitution, Art. 6, Clause 2.

10. Ibid.

11. An Act to Provide for the Reorganization, Supervision, and Maintenance of Common Schools, 1853 Ohio Laws 429 (March 14, 1853).

12. Fortin, Faith and Action, 114-115.

13. Margaret C. DePalma, Dialogue on the Frontier: Catholic and Protestant Relations, 1793-1883 (Kent, OH: Kent State University Press, 2004), 127.

14. "Free Schools in Ohio-Address of the Catholic Archbishop," New York Daily Times, March 31, 1853, 3. 
Council Chamber and the School Board"15_all those who denied Catholics the right to a tax-funded education. While the archbishop did not go so far as to mandate voting for specific candidates, he did mention some current officials who were "on the right side of the questions at issue." l6

Purcell's letter was published only days before city elections and served to make free public education a major issue. While the traditional parties focused on other strategies, a Free School party campaigned specifically on that issue, nominating James D. Taylor for mayor of Cincinnati. ${ }^{17}$ The party's primary goal was to protect tax dollars from apportionment to sectarian schools. Taylor, the editor of the anti-Catholic Cincinnati Times, garnered $35 \%$ of the popular vote, losing narrowly to the Democratic candidate, David Snelbaker, who received 39\%. ${ }^{18}$

Anti-Catholic sentiment was further stoked later in the year when a mob gathered to protest the visit of papal emissary Archbishop Gaetano Bedini to the city. The mid-1850s saw the rise of the nativist Know-Nothing movement. While the Ohio Know-Nothings did not coalesce into one specific political party, most would eventually find their way into the nascent Republican Party and bring with them their anti-Catholic and anti-immigrant ideas. In 1856 the Ohio legislature passed "An Act in relation to Conveyances and Devices of Property for religious purposes" which mandated that control of religious properties belonged to all members of the religious group that owned it. ${ }^{19}$ The legislation outlawed the Catholic practice of placing church properties in the name of the local ordinary, the bishop.

In 1858 Archbishop Purcell convened a meeting of regional Catholic bishops, the Second Provincial Council of Cincinnati, which issued strong and specific directives regarding the education of children. Decrying yet again the hostility of the common schools to the Church and bemoaning the implacability of those refusing Catholic access to tax-generated funding, the council made it the duty of every faithful parent to send their children to Catholic schools. Pastors in the province were obligated under the pain of mortal sin to provide a Catholic school in every parish under their care. ${ }^{20}$ In

\section{Ibid.}

16. Ibid

17. Tyler Anbinder, Nativism and Slavery: the Northern Know-Nothings and the Politics of the 1850s (New York: Oxford University Press, 1992), 25.

18. William E. Gienapp, Origins of the Republican Party: 1852-1856 (New York: Oxford University Press, 1987), 64.

19. Thomas W. Kremm, "The Old Order Trembles: The Formation of the Republican Party in Ohio," Cincinnati Historical Society Bulletin 36 (1978), 193-215, 197.

20. Acta et Decreta Quator Conciliorum Provincialium Cincinnatensium, 1855-1882 (Cincinnati: Typis Benziger Fratrum, 1886), 62. 
the three decades since his arrival, Archbishop Purcell's relative openness to public education had hardened into the belief that Catholic children would not be treated fairly in the common schools. This, then, required the Church to shoulder that responsibility in the growing network of parochial schools across the state. The outbreak of the Civil War brought a suspension of hostilities in the battle between proponents of public and parochial schools but this proved only temporary.

\section{Post-war Republican Politics and Catholic Education}

A Union victory and the tragic death of President Lincoln cemented the political power of the radical Republicans in the immediate post-Civil War era. Many had journeyed from the old Whig Party through the KnowNothing movement before joining the newly-formed Republican Party as the slavery issue heated up. One such radical was Chief Justice Salmon P. Chase who, as Governor of Ohio, had signed the anti-Catholic property bill of 1856 into law. The evolution of the Republican Party retained some elements of its earlier political iterations, most pertinently the high value the Whigs had placed on the purpose of the common schools and the nativist anti-Catholicism of the Know-Nothings. Both of these elements would take center stage in the postwar resumption of the public vs. parochial school feud.

In March 1870, Harper's Weekly published an illustration by famed cartoonist Thomas Nast entitled "Fort Sumter" depicting the public schools of the United States being attacked by an "ecclesiastical canon" manned by a Catholic priest and his doltish minions. Inspiration for the attack was provided by a quotation from Cardinal Giacomo Antonelli, papal Secretary of State, proclaiming freedom of education as against the laws of God and the Church. ${ }^{21}$ Appearing less than a decade after the actual bombardment of Fort Sumter and the carnage that ensued, the meaning of the illustration would be painfully obvious to most Americans. Unlike the real attack, Nast's version represented a renewal of hostilities that stretched back nearly thirty years into the early days of the Common School movement. For many Republicans, the symbolism of the cartoon accurately described the next great threat to the unity of the United States: the balkanization of American society through the development of competing school systems. While this threat was not new, the increasing presence of the Catholic Church made it more urgent than ever to those who viewed the public school as the means to forge and perpetuate a common American society.

21. Thomas Nast, “Fort Sumter,” Harper's Weekly, March 19, 1870. 


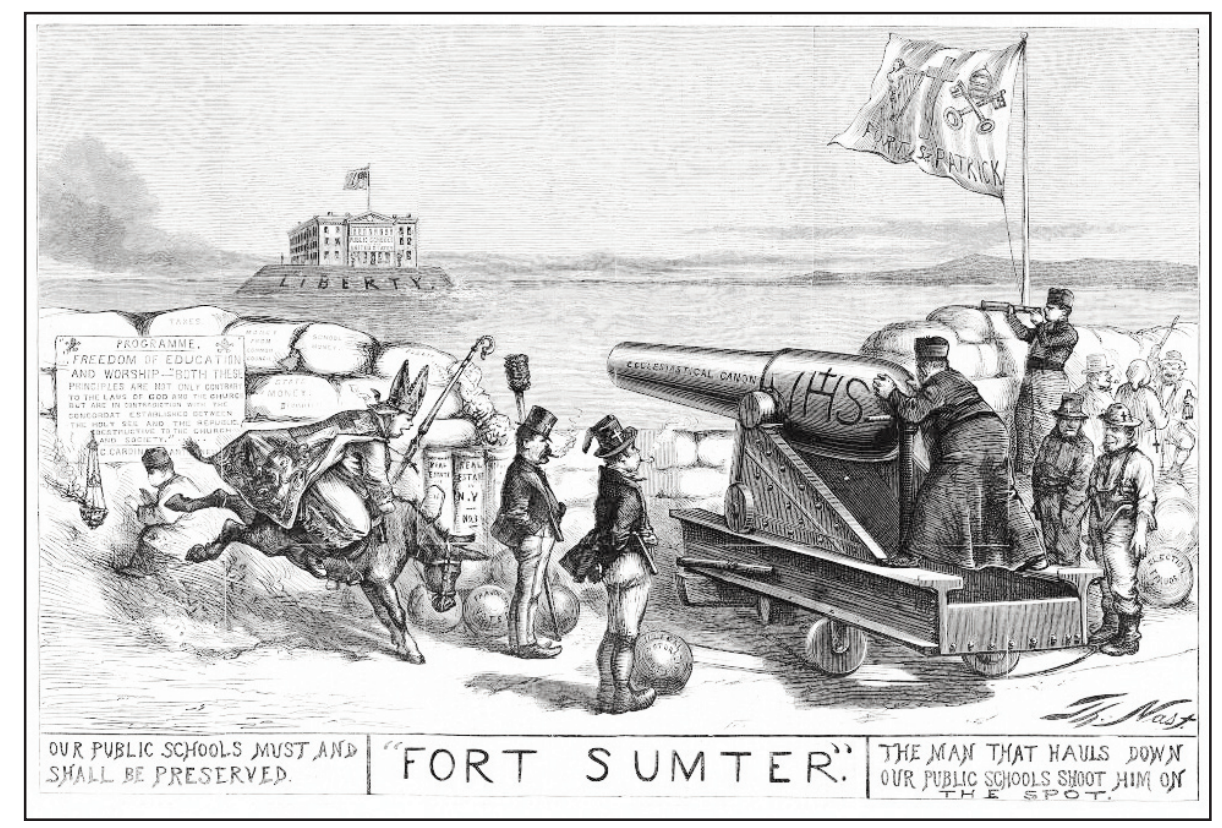

Thomas Nast depicts the public schools besieged by Catholic forces in a cartoon titled, "Fort Sumter," an allusion to the location of the bombardment that began the Civil War (Harper's Weekly, March 19, 1870).

Nast's drawing continued his ongoing condemnation of what he saw as collusion between Tammany Hall-the Irish-dominated New York political machine - and the Catholic Church. ${ }^{22}$ In 1869, William "Boss" Tweed had successfully shepherded a bill through the New York state legislature to grant funding to private schools with more than 200 students. Typically, the only private schools that large were Catholic schools. Education historian Ward McAfee reports that one Catholic politician celebrated the bill's passage by crowing, "This is the little finger, and we must persevere "til we get the whole hand," presumably into the public till. Although the bill was soon repealed, private schools managed to extract over $\$ 200,000$ from the public coffers in the law's first year. ${ }^{23}$ Though Tweed's corruption was notorious at this point and would soon land him in jail and disgrace, Republican legislators worried similar abuses could soon follow in other states. Ohio was one such state where Republican lawmakers would not only protect public school funding from sectarian hands but, in addition, actively work to hamper the survival of the parochial school system.

22. Benjamin Justice, "Thomas Nast and the Public School of the 1870s," History of Education Quarterly 45, no. 2 (Summer 2005), 171-206, 183.

23. Ward M. McAfee, Race, Religion and Reconstruction: The Public School in the Politics of the 1870s (Albany: State University of New York Press, 1998), 57. 
While New York politicians grappled with the "little finger" in the till, Ohio Republicans worried about the "pope's toe" wriggling open the metaphorical door that barred Catholic access to public school funds. The 1860s brought significant growth to the Catholic presence in the state. In 1860, the Metropolitan Catholic Almanac reported 210,000 Catholics in Ohio served by 223 parishes and 100 schools. Ten years later that number had grown to 335,000 Catholics in 284 parishes and 189 schools. The decennial census of 1870 reported a little more than $12 \%$ growth in statewide population, but the almanac showed a $63 \%$ increase in the number of Catholics in Ohio during that same period. ${ }^{24}$ Even if unaware of the numbers, citizens of Ohio's cities-especially Cincinnati, Cleveland, and Toledo-could not help but notice the steady expansion of Catholic churches and schools in their neighborhoods.

With slavery abolished, the Republican Party sought to rebuild a fractured nation and prevent future schism. The public school represented a means of unity by using the common experience of education to create bonds transcending race, religion or economic class. Harkening back to its Whiggish roots, the Republican Party promoted public education as the crucible which would produce a common American culture. ${ }^{25}$ The accelerating growth of Catholic education in this era represented the most significant obstacle to this new priority of the Grand Old Party whose members sought to undermine the Church's ability to educate its youth.

\section{The Cincinnati Bible War}

Although Thomas Nast portrayed the Catholic Church as the aggressor in this new war, the first shot in Ohio came from the other direction. At a meeting of Cincinnati's public school board in early September 1869, a nonCatholic member, Samuel Miller, introduced a resolution to ban the use of any religious books (including the Bible) from the city's schools. His professed purpose was to allow children of parents of all sects and opinions in matters of faith to "enjoy alike the benefits of the common school fund." 26 The timing of his proposal is notable because it happened at a meeting at

24. Metropolitan Catholic Almanac and Laity's Directory of the United States (Baltimore: John Murphy, 1860), 95-98; Metropolitan Catholic Almanac and Laity's Directory of the United States (Baltimore: John Murphy, 1870), 76, 162, 165; "Resident Population and Apportionment of the U.S. House of Representatives," https://www.census.gov/dmd/ www/resapport/states/ohio.pdf.

25. McAfee, Race, Religion and Reconstruction, 5-6.

26. Stephan F. Brumberg, "The Cincinnati Bible War (1869-1873) and its Impact on the Education of the City's Protestants, Catholics, and Jews," American Jewish Archives Journal 54 (2002), 11-45, 22-23. 
which the school board discussed the possibility of developing some system of cooperation with the parochial school system of the Archdiocese of Cincinnati. This possibility had begun as the initiative of another school board member. It died quickly but its proximity to the Miller proposal was enough to ignite what would become known as the Bible War.

Archbishop Purcell played a fairly minimal role in the so-called Bible War. He had been away from the city when members of the school board made their first overtures toward cooperation and his own reaction to the idea could only be described as tepid. Purcell professed his satisfaction with the current parochial system in place and the conditions he stipulated for cooperation effectively killed any possibility of the proposal coming to fruition. The archbishop concluded that he would be open to any plan emulating the school systems of England, France or Prussia-all places where sectarian schools received a proportion of tax dollars for education. ${ }^{27}$ Toward the end of 1869, Purcell embarked for Europe to participate in the First Vatican Council while the Bible War played itself out in his absence.

When Miller's proposal became public, it immediately generated controversy across the city. In late September two hundred people rallied in favor of the idea. ${ }^{28}$ Two days later an even larger rally demanded the Bible be retained. On November 1, by a vote of twenty-two to fifteen, the school board resolved to prohibit any use of the Bible in the city's public schools. ${ }^{29}$ Opponents quickly took the issue to court and were granted an injunction stalling implementation of the resolution. ${ }^{30}$ In early 1870, the Superior Court of Cincinnati ruled by a vote of two to one against the school board and made the injunction permanent. ${ }^{31}$ This decision was dismissed in February 1873 by the Ohio Supreme Court which ruled that the courts had no lawful authority to determine what books were used in the classroom. Such decisions should be left to each local school board. ${ }^{32}$

The controversy generated by the Bible War had ramifications for a later controversy as well. The lone dissenter in the Superior Court decision was Judge Alphonso Taft, a liberal Unitarian who argued that reading the Bible in schools violated the religious freedom of the students who did not espouse the values of the Protestant majority. ${ }^{33}$ At that time Taft's political fortunes

27. Ibid., 23-24.

28. DePalma, Dialogue on the Frontier, 135.

29. Cleveland Plain Dealer, November 2, 1869, 2.

30. "The Religion War in Cincinnati," Cleveland Plain Dealer, November 3, 1869, 2.

31. DePalma, Dialogue on the Frontier, 136.

32. Brumberg, "The Cincinnati Bible War," 29.

33. Ibid., 31 . 
were on the rise in the Republican Party, but his dissent in this case effectively undermined his nomination as the Republican candidate in the gubernatorial election of 1875. Instead, the nomination would be given to Rutherford B. Hayes who ran a campaign predicated on stopping the "threat" of Catholic political influence in the state.

\section{Taxation of Catholic Schools}

In 1873 Hamilton County auditor Walker Yeatman and treasurer John Gerke placed the parochial schools of Cincinnati on the county tax rolls. Archbishop Purcell's attorneys quickly requested and were granted an injunction against paying until the legal ramifications could be sorted out. Attorneys for Hamilton County argued parochial schools were taxable because they did not qualify for exemption either as churches or public schools. The argument that parochial schools were not used for worship and, therefore, could not qualify as churches was straightforward enough. The core of the Hamilton County argument was the word "public" connoted schools supported by tax dollars and, therefore, Catholic schools did not fit the criteria for exemption. Attorneys for the archdiocese derided that argument as erroneous, arguing that "public" defines purpose, not source of funding. Any facility open to all people should be defined as public. Because Catholic educational institutions were open to all who wished to attend, they did fit the legal description of being a "public" school. ${ }^{34}$ The judges of the Superior Court in Cincinnati were unimpressed with either argument. In June 1873 the judges ruled in Gerke v. Purcell that since parochial schools benefitted the general welfare without regard to profit, they qualified for tax exemption as public charities. ${ }^{35}$ This rendered moot the question of whether Catholic schools could be considered public.

Two years after the decision, Bishop Richard Gilmour of Cleveland received a bill for taxes assessed against the Catholic schools of Cuyahoga County. Like their counterparts in Hamilton County, L. D. Benedict, treasurer, and Frederick W. Pelton, auditor, were both Republicans. Bishop Gilmour refused to pay the taxes and the school properties were subsequently listed as delinquent and offered for public sale. As in Cincinnati, the diocese filed a request for an injunction against the settlement arguing that Gerke v. Purcell had established parochial schools as public charities exempt from taxation. Attorneys for Cuyahoga County countered parochial schools prevented Catholic children from being exposed to the spirit of toleration intended when Ohio's system of public schools was established. This subver-

34. Gerke v. Purcell, 25 Ohio State 225 (1874).

35. Ibid. 
sion of the public policy of the state of Ohio negated any pretense of the Church's schools being charities. ${ }^{36}$ Judge J. M. Jones of the Cuyahoga County Court of Common Pleas did not find the county's case compelling. In his verdict he pointed out the state of Ohio had no specifically religious policy to contradict and there was little evidence the schools of the diocese opposed any policy. ${ }^{37}$ The decision would be appealed by Cuyahoga County and, in 1883, the Supreme Court of Ohio upheld Jones' initial ruling. ${ }^{38}$

The strategy of impeding the growth of parochial education by taxing the schools was neither new nor unique to Ohio. In 1870 the state legislature in Rhode Island passed a law limiting the amount of church property exempt from taxation. The scope of that law was eventually expanded to remove all exemptions for church schools. After surviving a challenge in court, that law would remain in effect until $1894 .{ }^{39}$ Once the local attempts at church school taxation failed in Ohio, Republican members of the state legislature moved to follow Rhode Island's example.

In January 1876, Representative Orlando J. Hodge of Cuyahoga County introduced a bill into the Ohio House mandating the taxation of church property. ${ }^{40}$ Hodge's purpose became clear in a speech to the House in March. He complained of the vast holdings being assembled by the Catholic bishops of Cleveland and Cincinnati. Hodge argued the state contributed \$750,000 annually to "the Atheists, the Deists, the Jesuits, the Buddhists, the Jacobites, the Mohammedans, the Jumpers, the Dancers, the Libertines, and all other so-called religious sects" who enjoyed the benefits of tax exemption disproportionate to what they contributed to the general good. ${ }^{41}$

Representative Hodge received strong support for his proposal from Edwin Cowles, publisher of the Cleveland Leader. Cowles, a staunch Republican, had been active in the party since its foundation. Moreover, he was an ardent nativist and anti-Catholic, serving as the local head of the Order of the American Union, one of several anti-Catholic organizations to sprout after the Civil War. Cowles, a man of strong opinions, used the Leader as the club he

36. Gilmour v. Pelton, 5 Ohio Dec. (Rep) 447.

37. "Catholic Property, Judge Jones Decision, In His Opinion the Church and School Property is Exempt," Cleveland Plain Dealer, July 12, 1877, 4.

38. Paul Hallinan, Richard Gilmour, Second Bishop of Cleveland 1872-1892 (Ph.D. dissertation, Western Reserve University, 1963), 298-299.

39. Robert N. Gross, Public vs. Private: the Early History of School Choice in America (New York: Oxford University Press, 2018), 55-56.

40. "Ohio Legislature," Cleveland Plain Dealer, January 4, 1876, 2.

41. Orlando J. Hodge, "Church Taxation," Speech delivered to the Ohio House of Representative, March 25, 1876. 
swung at Catholics and Democrats with equal gusto. ${ }^{42}$ In an editorial Cowles argued that Hodge's proposal would protect the United States from suffering the same fate as Spain, Mexico, and Italy-all under the Catholic thumb. ${ }^{43}$

As a young man Hodge had attended a Free Will Baptist school, Geauga Seminary, located east of Cleveland. He was a classmate of James Garfield, another Ohio Republican who shared Hodge's views on church taxation. Two years earlier, while representing Ohio's Nineteenth Congressional District, Garfield served as chair of the House Appropriations Committee. During a discussion of appropriations for the District of Columbia, Garfield objected to an amendment to the bill awarding $\$ 25,000$ to the Little Sisters of the Poor for their work in the city. As a way of explanation he stated:

The divorce between Church and State ought to be absolute. It ought to be so absolute that no Church property anywhere, in any state or in the nation, should be exempt from equal taxation; for if you exempt the property of any church organization, to that extent you impose a tax upon the whole community. ${ }^{44}$

Interestingly enough, Garfield made his objection just after he had concurred on a similar amendment giving funds to the Women's Christian Association of Columbia. Other House Republicans objected to Garfield's attitude toward the Little Sisters by citing Catholic sisters' service during the Civil War. Benjamin Butler of Massachusetts specifically lauded the Sisters of Charity for their work with his troops suffering from malaria and fever in Louisiana. ${ }^{45}$ This indicates a lack of consensus among Republican leaders on the issue of government support for religious institutions.

Hodge's taxation proposal never gathered much momentum, but other Ohio Republicans would make similar proposals in the legislature over the next few years, none of which garnered much support. Garfield continued to promote taxation of religious institutions, especially schools, emphasizing the plan in campaigning for Hayes in the 1875 Ohio gubernatorial race. ${ }^{46}$ He may have held this view as late as 1880 when the party's platform included a plank supporting the passage of a constitutional amendment forbidding the appropriation of public funds for sectarian schools. ${ }^{47}$ The idea of

42. "Edwin W. Cowles," in Encyclopedia of Cleveland History, http://case.edu/ech/ articles/c/cowles-edwin-w/.

43. "Hodge's Church Taxation Bill," Cleveland Leader, March 4, 1876, 4.

44. Congressional Record, 43rd Cong., lst sess., 1874, 2, pt. 6:5384.

45. Ibid.

46. "Garfield," Cleveland Daily Herald, September 1, 1875, 2.

47. Proceedings of the Republican National Convention (Chicago: Republican National Convention, 1880), 162. 
such an amendment was nothing new. It had been proposed by Senator James G. Blaine five years earlier and several states, including Ohio, already had such a clause in their own constitutions. In his letter accepting the Republican presidential nomination that year, Garfield affirmed the platform and more, advocating for the complete separation of church and state in all matters of taxation. ${ }^{48}$ Although he would not live long enough to act on this idea, Garfield's attitude toward the Catholic presence was more radical than that of other members of his party.

The events of 1875 proved to be the high water mark in the ongoing conflict between church and state in Ohio. Frederick Pelton forced the issue by placing the Catholic schools of Cuyahoga County on the tax rolls. In his annual address to Congress, President Ulysses Grant took up Garfield's theme and recommended the taxation of all church properties except for cemeteries and possibly church buildings. ${ }^{49}$ Most notably, the gubernatorial election of that year weighed a proposal to give prisoners more freedom of religion with Republicans judging the bill as an incursion of the "pope's toe" into the state institutions of Ohio.

\section{The Geghan Bill and the Election of 1875}

John J. Geghan, an Irish-Catholic from Cincinnati, was elected to the Ohio House of Representatives in 1873. Though his party loyalties were somewhat fluid, Geghan had campaigned as a Democrat. It was a fortunate choice because the elections of 1873 brought a return to power for the Democratic Party. The party won a majority of seats in the legislature and seventy-year-old William Allen was elected governor by a mere 817 votes. ${ }^{50}$ Geghan's own victory may have been narrow as well. In the electoral process at that time, the top ten vote-getters among the candidates running in Hamilton County won election to the House of Representatives. When the returns were first reported, Geghan placed thirteenth among thirty candidates. ${ }^{51}$ The next day, however, a short paragraph appeared in The Cincinnati Daily Enquirer announcing that there had been an error in tabulation and Geghan was elected along with eight other Democrats and one Republican to represent Hamilton County. ${ }^{52}$ Geghan served only one term but that was sufficient to stir up a controversy that would have national implications.

48. Ibid., 299.

49. Ulysses S. Grant, "Seventh Annual Message," December 7, 1875.

50. "Later Election Results," Cleveland Plain Dealer, October 15, 1873, 2; Jean H. Baker, "Allen, William," in American National Biography Online, http://www.anb.org/.

51. "Election Results," Cincinnati Daily Enquirer, October 21, 1873, 4.

52. Cincinnati Daily Enquirer, October 22, 1873, 4. 
In February 1875 Geghan introduced House Bill 615. That bill's stated purpose was to allow inmates in state institutions to have access to ministers from their own religious denominations. ${ }^{53}$ This changed the current practice of appointing one clergyman-often Protestant - to minister to an entire institution. Democratic and Catholic newspapers across the state welcomed the bill as a step toward greater religious freedom for Catholic prisoners. An editorial in Cleveland's The Catholic Universe proclaimed:

The text of this bill, which we publish elsewhere in our columns, claims the attention of our readers. . . . It draws its inspiration from the American Constitution, and is in strict accordance with the spirit and letter of our own Bill of Rights. The liberty of conscience which these instruments guarantee in words, it would secure in fact for all people of this common-wealth. Here we should have no State-favored religion, and this bill asks nothing for the professors of one creed which it would not extend to the adherents of all other creeds. ${ }^{54}$

Similarly, The Cincinnati Daily Enquirer argued Geghan's bill helped to eradicate establishmentarianism by opening the doors of Ohio's institutions to all religions, not just those chosen by public officials. ${ }^{55}$

Opponents of the bill were not so sanguine about its purpose. When it passed, the Leader's Edwin Cowles accused it of insinuating the tentacles of Rome ever deeper into American life. ${ }^{56}$ Later Cowles would cite dark predictions printed in similar newspapers across the state. According to the Cincinnati Gazette, Catholic priests would use their new-found access to Ohio's institutions to proselytize a literally captive audience. The Sandusky Register worried Catholics would be ordered from the pulpit to vote the Democratic ticket. ${ }^{57}$

The Register's fears were not without substance; three weeks earlier Geghan himself had publicly appealed to Catholic voters to pressure their representative to support his bill. In the Catholic Telegraph of Cincinnati, the erstwhile legislator proclaimed:

We [Catholics] have a prior claim on the Democratic party. The elements composing the Democratic party in Ohio to-day-fully two thirds of said party - are made up of Irish and German Catholics, and they have always been loyal and faithful to the interests of the party.

53. "Ohio Legislature," Cleveland Daily Herald, February 18, 1875, 1.

54. "The Geghan Bill," [Cleveland] Catholic Universe, March 6, 1875, 4.

55. "Since the Geghan Bill has Passed," Cincinnati Daily Enquirer, April 1, 1875, 4.

56. "Sectarianism in Prison-Mr. Geghan's Substitute," The Cleveland Leader, March $26,1875,4$.

57. "The Geghan Iniquity," The Cleveland Leader, April 2, 1875, 4. 
Hence the party is under obligation to us, and we have a perfect right to demand of them . . they should as a party redress our grievances. ${ }^{58}$

An editorial in that same edition of the Telegraph took Geghan's plan and transformed it into an ultimatum:

The political party with which nine tenths of the Catholic voters affiliate ... now controls the State. Withdraw the support which Catholics have given to it, and it will fall in this city, county and State as speedily as it has risen to its long lost position and power. That party is now on trial . . . if they persist in their opposition, it will be the duty of Catholic citizens to teach them that there is method in their supposed insanity. ${ }^{59}$

And while Archbishop Purcell had not offered this ultimatum, Father Edward Purcell, the archbishop's brother and editor of the Telegraph, had often served as Catholic spokesman when his brother was away from the city, leaving the archbishop's detractors to believe that this was the archbishop's opinion.

The Ohio legislature passed the Geghan Bill during the session's final day in early 1875. The Telegraph celebrated the decision: "The unbroken, solid vote of the Catholic citizens of the State will be given to the Democracy at the Fall election." 60 This incautious statement handed the Republican Party the focus of their campaign strategy for the upcoming gubernatorial election and provided fodder for Republican newspapers speculating about Catholic interference in American democratic processes. Edwin Cowles used the statement to accuse Catholic voters of taking orders from the archbishop of Cincinnati who had been commanded by Rome to destroy the public school system. ${ }^{61}$ His paper referred to the "unbroken, solid vote" almost weekly to remind readers what was at stake in the fall elections. The Telegraph tried to put the genie back in the bottle the following week by averring:

We have no politics; we are no partizan; we know nothing of parties except when Catholic interests are involved, when Catholic rights are endangered. As American by birth, we even abstain from voting, that no one may impute in our office any political bias or prejudice. ${ }^{62}$

58. "Representative Geghan," [Cincinnati] Catholic Telegraph, March 11, 1875, 1.

59. "The Removal of a Grievance," [Cincinnati] Catholic Telegraph, March 11, 1875, 4.

60. [Cincinnati] Catholic Telegraph, April 1, 1875, 4.

61. "The Catholic Telegraph of Cincinnati. . .," The Cleveland Leader, April 5, 1875, 4.

62. "Our Protestant and 'Liberal' Catholic Contemporaries," [Cincinnati] Catholic Telegraph, April 8, 1875, 4. 
Democratic newspapers like the Cleveland Plain Dealer reprinted this statement to reach a larger audience, but this latter statement did not undo what had been written. ${ }^{63}$

While Republican editors like Edwin Cowles made hay with the Telegraph's intemperate remark, Democratic newspapers worked to move public opinion in the other direction. The Cincinnati Daily Enquirer thus complained about the Telegraph's editor, Father Purcell:

He makes it a point to always saddle some indiscreet, idiotic utterance upon the Democratic party on the eve of the election. If he was [sic] the open enemy of the organization he couldn't do more injury. The Democratic party is the party of liberalism and the foe of intolerance. The Catholic Church receives at its hands just what all other churches and religions receive. It asks the suffrages of all people who believe in religious liberty. It doesn't crave the blessing of the Catholic Church and doesn't ask that Catholics shall be ordered to vote its ticket. We would like to see one election in Hamilton County when the Democratic Party wasn't handicapped with the religious issues begotten by the zealots of the Catholic Telegraph and the Presbyterian infidels of the Gazette. ${ }^{64}$

With the Enquirer's excoriation, the battle lines between the three major institutional players on this issue were set. The Republicans accused the Democrats of being under the sway of Catholic influence. The Democrats constantly pledged their commitment to religious equality and the protection of the public schools from sectarian influence. The Catholic press would muddy the waters of debate by promoting the division of the public school funding as an expression of both religious liberty (while everyone else seemed to interpret such a move as exactly the opposite) and supporting the interests of the Democratic Party while accusing Republicans of resurrecting old Know-Nothing tendencies.

After the spring campaigns brought Democratic victories in Cleveland and Cincinnati, Edwin Cowles discovered a larger danger lurking in the apparently harmless bill meant to bring religious comfort to Ohio's prisoners. In an editorial published two days after the April 1875 election, the Leader explained away the unhappy results by attributing them to the recent influx of foreigners in the state's urban areas-foreigners who voted Democratic and brought with them a moral blight that turned Ohio's fair cities into stains upon the land. Citing New York state as an example where the Republican faithful in the countryside "fought against the vicious political

63. Cleveland Plain Dealer, April 9, 1875, 4; Cleveland Plain Dealer, April 11, 1875, 4. 64. "The Catholic Telegraph. .. ," Cincinnati Daily Enquirer, April 7, 1875, 4. 
tendencies of the city wherein [Boss] Tweed was for years supreme," Cowles then called on the rural citizens of Ohio to similarly save their cities. ${ }^{65}$

In the same editorial, Cowles hit upon the key difference between the Geghan bill and the other Catholic controversies in Ohio. The Bible War and efforts to tax parochial school property in Cleveland were local issues confined either to Hamilton or Cuyahoga Counties, both of which had sizeable Catholic populations. Because the Geghan bill came from the state legislature, however, it represented the first encroachment of "the pope's toe" at a statewide level. The transition from local to state politics also shifted the balance of political power surrounding "the Catholic issue" because the rural counties of Ohio brought more Republicans to the fray than Democrats. ${ }^{66}$ This would not be lost on Republican leaders as they laid their plans for the fall campaign.

As the journalists continued to flog the Geghan issue on an almost daily basis, the parties prepared for their upcoming state conventions. Of several potential Republican nominees for the governorship, former governor Hayes seemed to have the widest support but he had steadily discouraged any efforts to nominate him for a third term. ${ }^{67}$ With Hayes out of the picture, Judge Alphonso Taft became the frontrunner, but his opinion in the Cincinnati Bible case made him suspect on the religious issue for many of his fellow Republicans. Many were not convinced of Taft's viability as a candidate, continuing to work behind the scenes lobbying Hayes to reconsider. William D. Bickham, editor of the Dayton Journal, tried to persuade the reluctant potential candidate that a successful run for governor could lead to the White House in 1876. For his part, Hayes did not think his chances for victory were very good and pleaded he was too involved in securing his family's financial footing to consider a return to politics. ${ }^{68}$ When Taft stepped aside, however, Hayes agreed to accept the nomination. ${ }^{69}$

While awaiting word of their nominee's acceptance, the Republican state convention crafted their platform for the upcoming campaign. This election would be crucial for the party for a number of reasons. The Democrats had been making steady progress in the state, having won thirteen of twenty Ohio congressional seats a year earlier and control of the state house in

65. "The Moral of It," The Cleveland Leader, April 7, 1875, 4.

66. Ibid.

67. "The Ohio Republicans," New York Times, June 1, 1875, 1.

68. Rutherford B. Hayes to W. D. Bickham, April 14, 1875, Diary and Letters of Rutherford Birchard Hayes (Columbus, OH: The Ohio State Archaeological and Historical Society, 1924), 269.

69. “3 June 1875," Diary and Letters of Rutherford Birchard Hayes, 274. 
1873. Congress had just passed the Resumption Act legislating redemption of paper money (greenbacks) with gold. Resumption was unpopular with the general public, still suffering from the Panic of 1873. Many believed that a reduction in the money supply would further depress the economy. The Ohio election, occurring in a populous state with large agricultural and industrial interests, would be a good indicator of whether the Republicans could run a "hard money" candidate in the 1876 presidential election. ${ }^{70}$ The party needed to run a campaign that promoted a complex economic policy while still providing an issue that could arouse passion and allegiance from the electorate. A healthy dose of anti-Catholic outrage might make the bitter pill of resumption easier to swallow.

The 1875 Ohio Republican platform featured twelve planks. The second plank addressed the greenback issue by advocating a gradual finance policy that would equalize the purchasing power of the coin and paper dollar. Plank four advocated no division of the state's school fund while the fifth plank reiterated the benefits of church-state separation. ${ }^{71}$ Hayes meanwhile, as recorded in his diary, developed his own strategy and his first priority was to attack the Democratic Party for its "subserviency to Roman Catholic demands." ${ }^{\prime 2}$ Later he elaborated, mentioning the corruption of the opposing party, its effect on state institutions, and the Catholic issue. ${ }^{73}$ The potential major issue of the campaign, greenbacks, did not merit a mention in Hayes' journal during the first few days of his candidacy.

When the Ohio gubernatorial campaign of 1875 began in earnest toward the end of August, it proceeded along three distinct but overlapping lines: the candidates' public rhetoric, behind-the-scenes political maneuvering, and the editorial jousting of the newspapers. Governor Hayes began his campaign with a speech in Marion, Ohio, which emphasized money and the schools. Having the time to prepare only one speech, his more than fifty campaign stops would follow the pattern of his first. ${ }^{74}$ Approximately twothirds of the way through the Marion speech, Hayes shifted his focus to the schools issue despite having said finances was the only part of the Democratic platform "which receives or deserves much attention." 75

70. Samuel DeCanio, "State Autonomy and American Political Development: How Mass Democracy Promoted State Power," Studies in American Political Development 19 (Fall $2005), 125$.

71. “Ohio Republicans," New York Times, June 2, 1875.

72. Diary and Letters of Rutherford Birchard Hayes, 274.

73. Ibid.

74. Rutherford B. Hayes to Guy M. Bryan, November 1, 1875, Diary and Letters of Rutherford Birchard Hayes, 296-297.

75. J. Q. Howard, The Life, Public Services and Select Speeches of Rutherford B. Hayes (Cincinnati: Robert Clarke, 1876), 243. 
Like other Republicans, Hayes made the usual connection between the Geghan Bill and the need to protect public school funding from sectarian purposes. Unlike Republican editors, however, Hayes was circumspect in identifying the villains in this issue. He was careful not to point directly at either the Democratic Party or the Catholic Church as a whole. While the candidate happily blamed the Democrats for many other problems, on this issue he was careful to refer only to the "sectarian wing of the Democratic Party."76 Regarding Catholics, Hayes was similarly cautious. He explicitly disavowed any wish to attack anyone on account of their religious convictions and thereafter referred to his culprits only as sectarians. ${ }^{77}$ The only time he used the word "Catholics" was in quoting the infamous passage directly from the Catholic Telegraph. While using the schools issue to rally popular support from his Republican base, he was careful to avoid alienating Catholics and Democrats who might be disposed to vote for him. Since, by his own admission, Hayes used the Marion speech as the template for the rest of his campaign speeches, ${ }^{78}$ it would be safe to assume that he followed the same strategy throughout the campaign.

Alphonso Taft, whose ambitions for the governor's mansion were thwarted by his role in the Bible War, played the good soldier during the 1875 campaign. On the evening of August 23, at Brainard's Opera House in Cleveland, Taft spoke specifically and exclusively to the public school question. He began by dismissing Democratic claims there was no issue in this regard and then acknowledged the innocuous nature of the Geghan Bill itself but pointed out the real danger lay in the manner of its passage. After discussing the Republican and Democratic state platforms on the issue, Taft asserted the Democratic Party, in its current position, could not be trusted to protect the freedom of Ohio's public schools. After making the distinction between the Catholic laity (generally positive) and the Catholic clergy (viewed as political meddlers), the judge explained his case for the secularization of Cincinnati schools as the fairest way of respecting all religions. $\mathrm{He}$ also claimed Archbishop Purcell was not satisfied with such equity and had not rested in his desire to promote sectarianism. After quoting extensively from various documents in the Bible War, letters from Archbishop Purcell, and even Pope Pius IX's Syllabus of Errors, Taft returned to the issue of the current campaign. He closed his speech:

Now, the Democracy must bear the responsibility of encouraging this sectarian war upon our schools. If it will court priesthood by such a

76. Ibid., 250 .

77. Ibid., 251

78. Rutherford B. Hayes to Guy M. Bryan, November 1, 1875, Diary and Letters of Rutherford Birchard Hayes, 296-297. 
means, let it bear the odium. We may only hope that both parties to this transaction may receive such a lesson in October as will discourage any further traffic of this kind. ${ }^{79}$

If Hayes was careful to tread lightly around the school issue in his public addresses, he showed no such compunction in his private campaign activities. As mentioned previously, even before accepting the nomination the once and future governor recognized the Geghan Bill's potential political capital. Hayes acknowledged to James Garfield that he would lose Republican votes on the currency issue but was consoled by the "almost wholly favorable" response to the "Catholic question."

In the planning stages of the campaign, the candidate urged the immediate publication of a pamphlet, in German and English, about the Geghan Bill and the school question. ${ }^{81}$ Ten days later, such pamphlets were in his hands and Hayes requested they be distributed at Republican gatherings across the state. ${ }^{82}$ While it is uncertain whether any of these documents are still extant, they excited the outrage of the Democratic press which accused them of trying to stimulate a new "Know-Nothing crusade" as part of the current Republican strategy. ${ }^{83}$

For the Republican newspapers in the state, the onset of campaigning did little to change the steady diet of sniping at the Democrats, exposing the latest "Romish" outrages and feuding with opposing editors. ${ }^{84}$ Considerable amounts of space were devoted to publishing the entire text of stump speeches considered to be important. For the most part, however, the editors preferred to hammer away at what they portrayed as the two "Catholic" issues: subverting the school fund and Catholic domination of the Democratic Party.

At the national level, Harper's Weekly weighed in against the Geghan Bill and its perceived implications in both word and image. Editor Eugene Lawrence commented on the Ohio election in almost every issue after the nominations were announced. In a May issue, Lawrence published an edito-

79. “Taft," Cleveland Daily Herald, September 24, 1875, 2.

80. Rutherford B. Hayes to James A. Garfield, June 28, 1875, Diary and Letters of Rutherford Birchard Hayes, 281.

81. Rutherford B. Hayes to A. T. Wickoff, July 8, 1875, Diary and Letters of Rutherford Birchard Hayes, 286-287.

82. Rutherford B. Hayes to A. T. Wickoff, July 19, 1875, Diary and Letters of Rutherford Birchard Hayes, 285-286.

83. "A Lying Document," Cincinnati Daily Enquirer, August 4, 1875, 4.

84. One such example occurred in June 1875 when the editor of the Cleveland Plain Dealer accused the Leader's Edwin Cowles of heading a secret anti-Catholic cabal. Cowles countered by offering $\$ 500$ if the Plain Dealer could provide proof. 


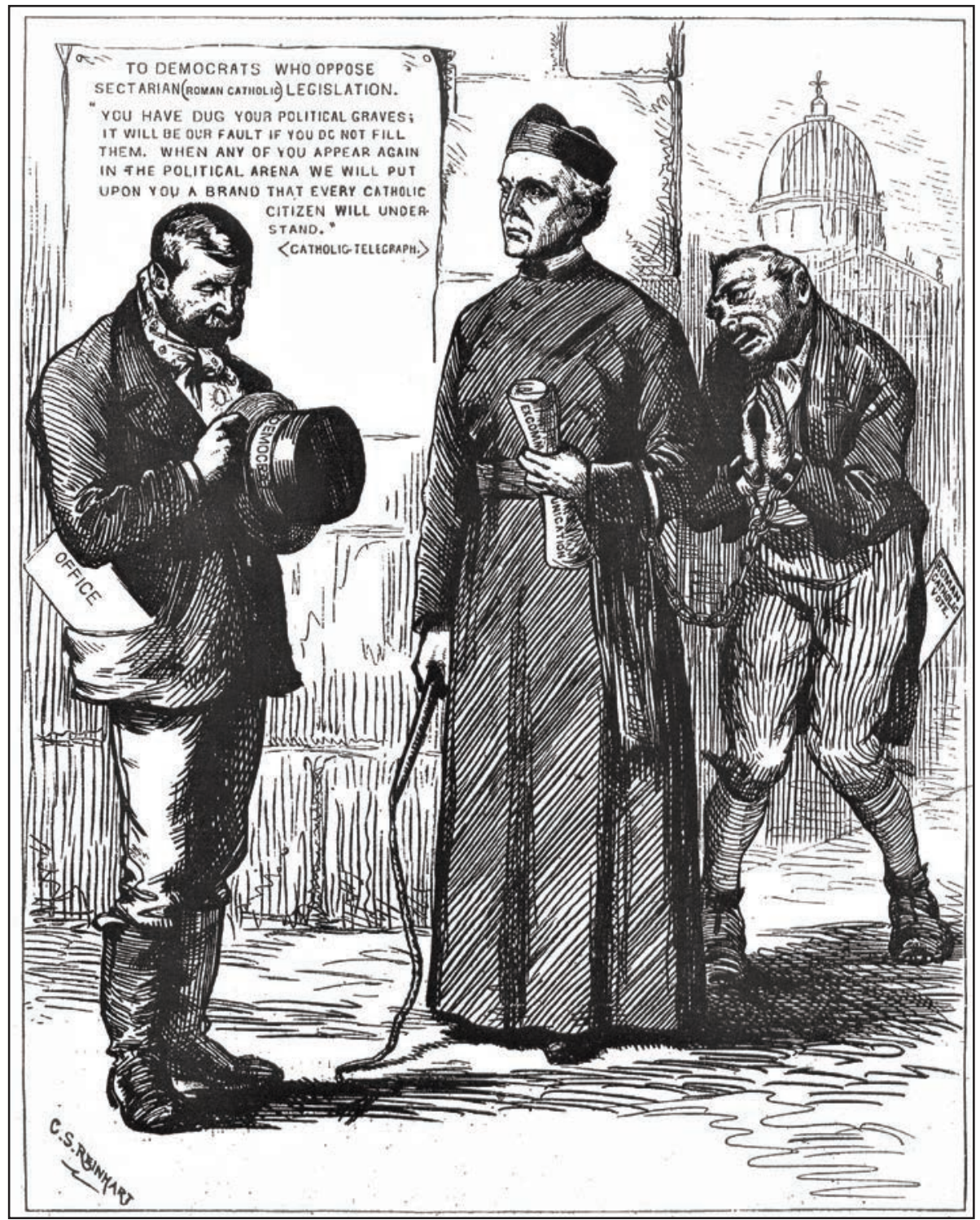

Harper's Weekly portrayal of the Catholic-Democratic alliance, crediting the Cincinnati Catholic Telegraph for its hyperbolic threat to Democrats in Ohio (Harper's Weekly, May 1, 1875). 
rial cartoon of a Catholic priest holding a whip in one hand and, in the other, a writ of excommunication. Over his arm was a shackle chaining together the hands of a very simian-looking Catholic voter. Standing before the priest, with eyes averted and hat in hand, is a Democratic office-holder. The caption included an allusion to the Telegraph's fateful pronouncement: "The unbroken solid vote of the Catholic citizens of the State will be given to the Democracy at the fall election."

Later that summer, Thomas Nast used the front page of an August edition to portray Archbishop Purcell enthroned on the "cathedra" of the State of Ohio with the Constitution under his feet. Over his left shoulder was a portrait of "St. Geghan" holding his eponymous bill. The illustration was full of smaller drawings and details offering additional critical commentary on the state of political affairs in Ohio.

On the other side of the campaign, the Democratic strategy seemed more diffuse, or less focused, depending on one's perspective. Their state convention opened on June 17 and quickly nominated William Allen for reelection. The convention fashioned a platform of fourteen planks, most of which were critical of Republican practices. The first twelve planks focused on national issues and gave some insight into Democratic concerns for the next year's national election. ${ }^{85}$ The thirteenth plank addressed the issue of the Geghan Bill and reaffirmed the Democrats' support for separation of church and state as well as their opposition to any division of the school fund. The plank concluded by denouncing the Republican platform as "an insult to the intelligence of the people of Ohio, and a base appeal to sectarian prejudices." 86

The thirteenth plank of the 1875 Ohio Democratic platform characterized the party's campaign that year, at least for its methodology if not its content. The school issue was significant for both sides in the election, but the plank's tone of reaction to opposing opinions seems to be the most common characteristic of the Allen campaign. Allen chose to focus primarily on the money issue and draw attention to the corruption of the government for which he blamed the Republican Party. ${ }^{87}$

Away from the stump, the Democrats seem to have emulated their opponents by publishing literature devoted to the Geghan Bill. Who produced the document is unknown, but the Library of Congress houses a broadside which seems to have been published in Ohio during the campaign. The front consists of quotations from the Ohio state constitution, the actual text of the Geghan

85. "Ohio Democrats," New York Times, June 18, 1875, 5.

86. Ibid.

87. “The Ohio Canvass," Cincinnati Enquirer, September 25, 1875, 1. 


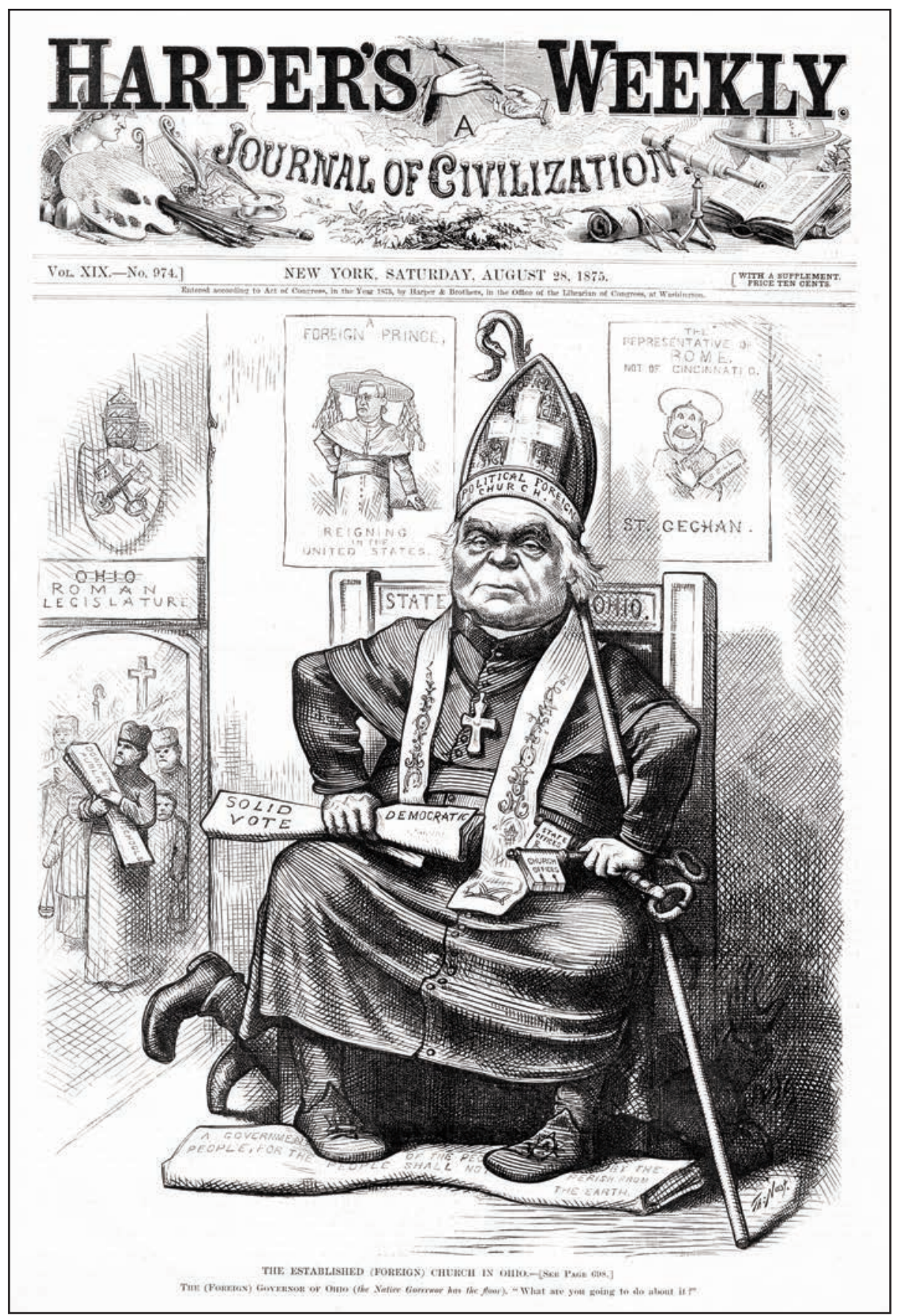

Thomas Nast's portrayal of Archbishop John B. Purcell of Cincinnati as "The (foreign) governor of Ohio." "St. Geghan" and his bill are depicted in the upper right of the cartoon; Geghan is, according to the cartoon, "a representative of Rome, not of Cincinnati" (Harper's Weekly, August 28, 1875). 
Bill, and the thirteenth plank of the Ohio 1875 platform. The back side explains the bill and condemns the Republicans for trying to restrict religious liberty. ${ }^{88}$

The Democratic cause was further impeded when Bishop Bernard McQuaid of Rochester, New York came to Cincinnati to address the Catholic benevolent associations in May 1875. McQuaid, a tireless builder of parochial schools, had established a national reputation as an advocate for sharing public education funds. ${ }^{89}$ After making his case on tax funding, the bishop exhorted Catholics to rise up and carry the issue to the ballot box to make known the will of the people. McQuaid's presence in Cincinnati at this time may be the best evidence of Archbishop Purcell's attitude in the Geghan controversy since McQuaid would not have taken the engagement without Purcell's approval.

Election day, October 12, finally arrived and brought with it beautiful weather and a large voter turn-out. ${ }^{90}$ When the polls closed, Rutherford Birchard Hayes had won an unprecedented third term as Governor of Ohio and was thus poised to make his run for the White House a year later. William Allen and John Geghan both went down to defeat and left electoral politics behind forever. Thomas Nast celebrated Geghan's defeat with a pithy turn of Catholic jargon.

Geghan dropped out of the public eye for a time only to emerge as a Republican again in 1884 when he was elected as Secretary of the Committee on Permanent Organization of the Irish-American Republican League, organized to support James Blaine's presidential campaign. ${ }^{91}$ Two years later, Governor Joseph B. Foraker, a Republican, appointed the former tobacconist as one of two assistant dairy commissioners in Ohio. Geghan's selection was greeted less than enthusiastically by the farming community: "We know nothing of St. Geghan's qualifications for the position, but we do know he is a politician, and particularly obnoxious to the Democratic party." 92

The bill named for Geghan did not long survive the installation of the new legislature. In January 1876, at the same session where Orlando Hodge proposed the taxation of church property, the House of Representatives voted to repeal the law. When Democratic legislators called for a motion for

88. "Religious Liberty Protected by the Constitution and the Geghan Bill," 1875, "An American Time Capsule: Three Centuries of Broadsides and Other Printed Ephemera," http://hdl.loc.gov/loc.rbc/rbpe.1380130b.

89. Jay P. Dolan, The American Catholic Experience (New York: Doubleday, 1985), 270-271

90. "Returns from Columbus," New York Times, October 13, 1875, 1.

91. "Delegates Meet in Convention at Cincinnati," New York Times, October 1, 1884, 1.

92. "Governor Foraker has appointed. . . ," Ohio Farmer, June 12, 1886, 24. 


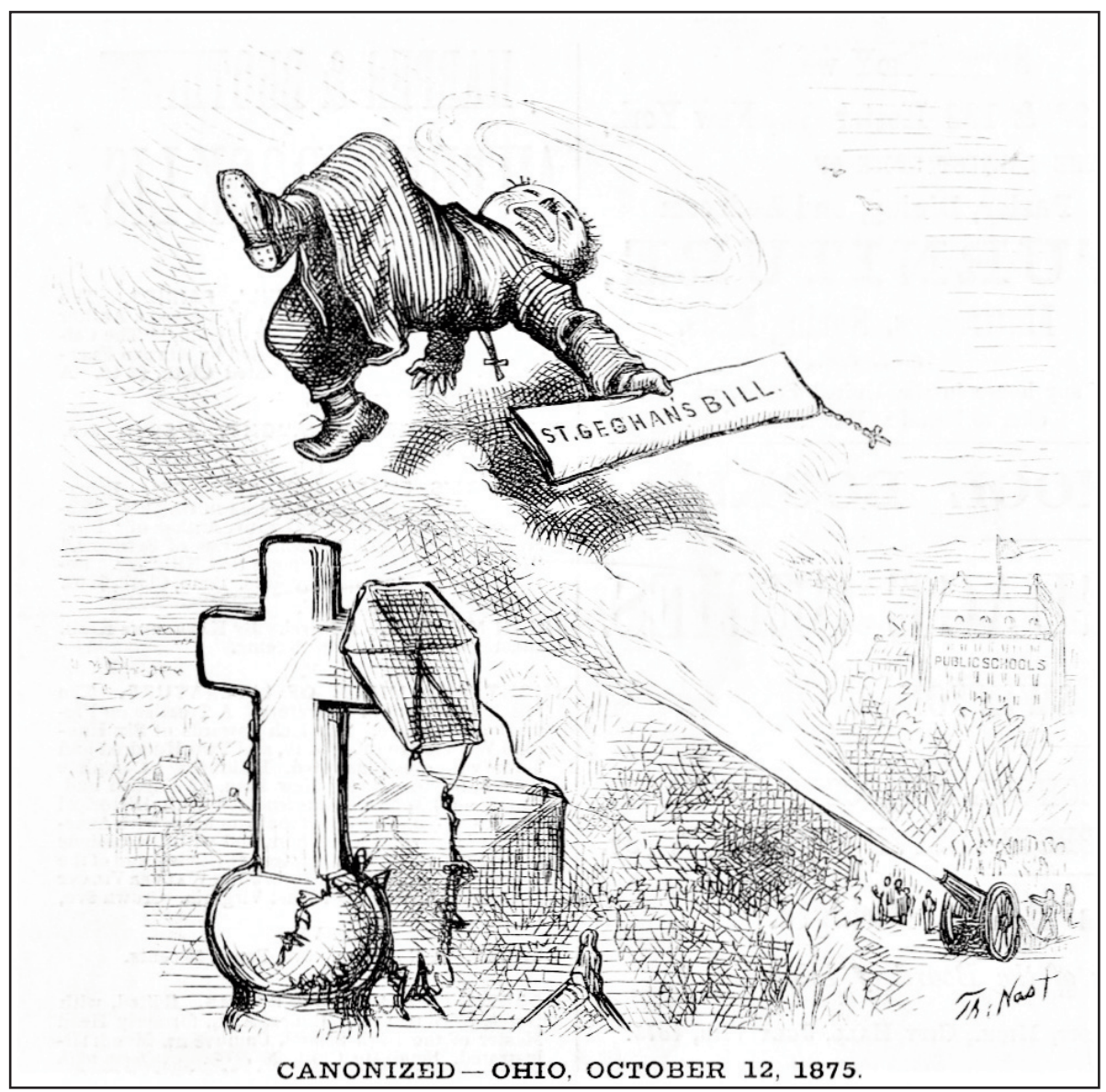

Thomas Nast celebrates the Democratic Party's defeat in Ohio in the cartoon titled, "Canonized-Ohio. October 12, 1875." Geghan and his bill are depicted as a casuality of the election (Harper's Weekly, November 13, 1875).

reconsideration, they were easily outvoted by the recently inaugurated Republican majority. ${ }^{93}$ A week later, the state senate followed suit and the Geghan Bill became a thing of the past. ${ }^{94}$ Commenting on the repeal, the Plain Dealer twitted a state senator from Cuyahoga County, who happened to be a physician, by noting that: "After the bill repealing the Geghan law passes the Senate, [Julius C.] Schenck will drop his title- 'chiropodist.' The Pope's toe will require no more attention at his hands." 95

93. "Ohio Legislature," Cleveland Daily Herald, January 22, 1876, 1.

94. “Ohio Legislature," Cleveland Daily Herald, January 29, 1876, 1.

95. “Our Columbus Letter," Cleveland Plain Dealer, January 25, 1876, 4. 
The repeal of the Geghan Bill effectively signaled the end of a chapter in the story of public and parochial education in Ohio. A wall of separation had effectively been established between the two entities that would last until the end of the twentieth century. With few exceptions, most of which were assiduously contested, public funding for education was reserved for the public schools of Ohio. Parochial schools, for their part, have enjoyed tax exemption based on the precedent established by Purcell v. Gerke. In 1996 Governor George Voinovich established the Cleveland Scholarship and Tutoring Program allowing selected families to use tax dollars to pay for tuition at private schools, including those run by the Catholic Church. In a subsequent court case, Zelman v. Simmons-Harris, the U.S. Supreme Court ruled that the Cleveland program did not violate the wall of separation because state funds were given to parents, who chose to direct them to parochial schools, rather than to sectarian schools themselves. ${ }^{96}$ In a bit of historical irony, a Republican governor of Ohio managed to accomplish exactly what his forebears a century earlier had fought so vociferously against.

\section{National Consequences}

Although the Geghan Bill itself was short-lived, the controversy surrounding it produced consequences affecting national politics for the remainder of the nineteenth century. In a recently published book, historian Samuel DeCanio devoted an entire chapter to the Ohio gubernatorial election of 1875 and argued that its successful outcome showed the Republican Party a clear path to success in the presidential election of 1876. Hayes' success in Ohio identified him as a viable candidate for the White House in an election that would be hotly contested. ${ }^{97}$ Though the election of 1876 would be much closer and more controversial than his race for governor, Hayes would prevail again and moved into the White House in 1877 where he presided over the end of Reconstruction, a return to the gold standard, and the beginnings of civil service reform. ${ }^{98}$

While the American style of democracy and the European model of Catholicism were diametrically opposed in many ways, there was one point on which both were in agreement and this, ironically enough, provided the locus for most of their conflict. Both entities recognized the importance of education as a means of perpetuating the values of their respective institutions and so, as each worked to make such education possible, the parallel

96. Zelman v. Simmons-Harris, 536 U.S. 639 (2002).

97. Samuel DeCanio, Democracy and the Origins of the American Regulatory State (New Haven, CT: Yale University Press, 2015), 145.

98. Ari Hogenboom, Rutherford B. Hayes: Warrior and President (Lawrence, KS: University Press of Kansas, 1995), 536-537. 
development of public and parochial schools provided the most frequent point of contact for a clash of values.

The ongoing conflict between public and parochial education that unfolded during Archbishop Purcell's career in Cincinnati established a sort of equilibrium between the two sides. The archbishop's early career was characterized by his attempts to find an acceptable place for Catholic students within the system of American education. When that failed, the prelate resorted to protest and political action. Eventually, he concluded that proper education for Catholic students could only happen without state support and directed his flock toward the parochial school system. Purcell's initial openness to and then his quick dismissal of the possibility of a merger of common and parochial school in 1869 is evidence that he might have accepted state support if it had been offered but recognized the futility of that possibility. While the archbishop provided a convenient target for Thomas Nast and for Judge Taft he did not participate in the post-war controversies as he had done in his early years. Nonetheless, his long tenure in Cincinnati made him the personification of the Catholic Church in Ohio.

On the other hand, the efforts of John Gerke, Orlando Hodge, and Frederick Pelton to limit the growing influence of the Catholic Church indicate a push in the other direction. While Purcell had worked to gain state support to cultivate Catholicism, postwar Ohio Republicans tried to use the power of the state to limit the Church's influence. Both sides draped their efforts in the banner of religious freedom and neither side achieved complete success. Just as Archbishop Purcell could not move the people of Ohio to support Catholic schools, Ohio Republicans could not convince the legislature or judiciary to remove tax exemptions - and indeed tacit support-for Catholic schools.

In another time or place, the Geghan Bill might have been seen as a modest step toward greater religious freedom. In 1870s Ohio, however, where religion was again a heated political topic, the passage of House Bill 615 ignited an explosive admixture of anti-Catholicism and political opportunism which propelled the Republicans back to power in Columbus and cleared a path to the White House. The irony is that a bill intended to allow more religious freedom was so easily made to look exactly the opposite. The acerbic commentator $\mathrm{H}$. L. Mencken wrote, "The whole aim of practical politics is to keep the populace alarmed (and hence clamorous to be led to safety) by an endless series of hobgoblins, most of them imaginary." 99 While the events of 1875 predate him, they prove his point: the politics of fear can be an effective strategy.

99. Henry L. Mencken, In Defense of Women (New York: Alfred A. Knopf, 1922), 53. 